\title{
Impact of Grape Temperature at Pressing on Organic Acids and Oenological Characteristics of Méthode Cap Classique Wines
}

\author{
B.S. Chidi ${ }^{1 *}$, M. Mafata ${ }^{2}$, N.Z. Notshokovu ${ }^{1}$, F. van Jaarsveld ${ }^{1}$
}

(1) ARC Infruitec-Nietvoorbij, Private Bag X5026, 7599 Stellenbosch, South Africa

(2) Institute for Wine Biotechnology, Department of Oenology and Viticulture, Private Bag X1, Stellenbosch University, Stellenbosch, 7600, South Africa

Submitted for publication: July 2017

Accepted for publication: February 2018

Key words: Méthode Cap Classique, organic acids, oenological, grape temperature, post-tirage, cultivar

\begin{abstract}
Maintaining the chemical composition of a wine is essential for the wine industry. Although the sugar-acid balance of a wine is of primary sensory importance, individual acids and oenological variables are equally important. The main focus of this study was to investigate the impact of grape temperature at harvest on the volatile acidity (VA), titratable acidity (TA), pH and alcohol levels, and the organic acid (citric, malic, pyruvic and succinic) characteristics of Méthode Cap Classique (MCC) wines produced from grape cultivars obtained from two regions in South Africa. Chardonnay and Pinot noir grapes were obtained from the Robertson (warm) and Elgin (cool) regions and were subjected to different temperature treatments, viz. $0^{\circ} \mathrm{C}, 10^{\circ} \mathrm{C}, 25^{\circ} \mathrm{C}$ and $30^{\circ} \mathrm{C}$, before further processing, including pressing, primary fermentation, blending, tirage, secondary fermentation, riddling and disgorging. The grape temperature was mostly responsible for the higher $\mathrm{pH}$ of the Robertson $\left(0^{\circ} \mathrm{C}\right.$ and $\left.10^{\circ} \mathrm{C}\right)$ and lower $\mathrm{pH}\left(0^{\circ} \mathrm{C}\right)$ of the Elgin post-tirage wines. Chardonnay-base wines from both regions that were vinified from grapes at lower temperatures $\left(0^{\circ} \mathrm{C}\right.$ and $10^{\circ} \mathrm{C}$ ) were richer in malic and succinic acid, while Pinot noir wines from both regions were characterised by higher malic, citric and pyruvic acid. Pyruvic acid was only detected after the secondary fermentations in wines from both regions. To our knowledge, this study is the first to investigate the influence of grape temperature on the oenological and organic acid characteristics of MCC wines in different regions and throughout different production stages.
\end{abstract}

\section{INTRODUCTION}

Méthode Cap Classique (MCC) wine is a sparkling wine produced using the traditional Champagne method in South Africa. The chemical composition of most wines is influenced by factors such as production area, grape variety, vintage, terroir and winemaking techniques (Jones et al., 2005; Coelho et al., 2009; Jones \& Alves, 2012; DobrowolskaIwanek et al., 2014). Although these factors are critical for wine characterisation and differentiation, their role in South African MCC wines still remains unclear. To date, very few studies have been done to evaluate $\mathrm{MCC}$ wines during different production stages (Torresi et al., 2011; MartínezLapuente et al., 2013), and none on the impact of grape temperature on oenological and organic acid characteristics of South African MCC wines.

In general, wine quality is attributed to the sugar-acid balance, hence acidity adjustment is a prerequisite in many wine cellars (Tita et al., 2006). Although total acidity is crucial in wine, all individual organic acids, such as succinic, pyruvic, acetic, citric, lactic, tartaric and malic acid play a critical role in defining the organoleptic character of the wine. They are important elements of the wine because of their sensory attributes (e.g. sour, sharp, tart, vinegar aroma, metallic and fresh) and their overall contribution to wine acidity (Mato et al., 2005). These acids are also fundamental for monitoring aspects of spoilage, ageing, and alcoholic and malolactic fermentation (Bisson et al., 2015). Malic, citric and tartaric acids are the main acids derived from grapes, whereas acids such as pyruvic, succinic and acetic are derived from fermentation (Volschenk et al., 2006). The sensory impacts of grape- and fermentation-derived acids are well known, since higher concentrations of these acids are associated with too much acidity, while lower concentrations are associated with flat, unacceptable wines (Lambrechts \& Pretorius, 2000; Shiraishi et al., 2010). There is limited knowledge of how changes in environmental/ fermentation conditions affect organic acid metabolism during fermentation, including the role of the tricarboxylic acid cycle (Fernie et al., 2004), glycolysis and the glyoxylate

*Corresponding author: E-mail address: chidib@arc.agric.za

Acknowledgments: We thank Stellenbosch University and the Agricultural Research Council, for providing research facilities. We also thank Charles Fox Wine Estate and Graham Beck Wines, for supplying us with grapes, and Simonsig Wine Estate, for the riddling, re-capping and disgorging of wines. Funding was provided by Winetech and the National Research Foundation (NRF) of South Africa (THRIP programme, grant number TP13080525717) 
pathway (Kornberg \& Madsen, 1958), which are the major drivers of organic acid production/consumption during alcoholic fermentation. The principal objective of this study was to investigate the influence of grape temperature on the oenological and organic acid characteristics of MCC wines, using standard MCC protocols adapted from the Cap Classique Producers Association (CCPA) and Graham Beck Wines, in an effort to understand how the chemical composition and organoleptic characteristics of MCC wines can be controlled.

\section{MATERIALS AND METHODS \\ Origin of grapes}

According to the climate information derived from Cape Farm Mapper (http://gis.elsenburg.com/apps/cfm, accessed on 19 June 2017), Robertson can be classified as a warmer production region than Elgin, based on mean monthly maximum and minimum temperatures. Chardonnay and Pinot noir grapes were sourced from these production regions to assess if a warm or cool production region may also affect the oenological variables and organic acid profiles of MCC wines.

\section{Vinification, Méthode Cap Classique protocol and sampling}

Chardonnay and Pinot noir grapes were collected from Elgin and Robertson farms for the 2015 vintage. They were harvested at $19^{\circ} \mathrm{B}$ sugar content and then transported to the ARC Infruitec-Nietvoorbij experimental cellar during the coolest hours of the morning. For each production region and cultivar, grapes were divided into four temperature groups (in triplicate) and stored in temperature-specific cold rooms, at $0^{\circ} \mathrm{C}, 10^{\circ} \mathrm{C}, 25^{\circ} \mathrm{C}$ and $30^{\circ} \mathrm{C}$, until probes inserted into the grape bunches confirmed that the grapes had reached and maintained the set temperatures. In the current study, lower temperature conditions are defined as those that were set and maintained at $0^{\circ} \mathrm{C}$ and $10^{\circ} \mathrm{C}$, while higher temperature conditions were set at $25^{\circ} \mathrm{C}$ and $30^{\circ} \mathrm{C}$.

Whole-bunch pressing (1 bar) of grapes was applied and the free-run juices were transferred into three separate $90 \mathrm{~L}$ drums, to which $50 \mathrm{mg} / \mathrm{L}$ of sulphur dioxide $\left(\mathrm{SO}_{2}\right)$ was added. The free-run juices were stored at $14^{\circ} \mathrm{C}$ and then sampled for routine analysis, but not for organic acids. The must was inoculated with $0.3 \mathrm{~g} / \mathrm{L}$ Saccharomyces cerevisiae IOC182007 yeast (CDS-Vintec, South Africa), after which $0.5 \mathrm{~g} / \mathrm{L}$ di-ammonium phosphate (DAP) was added to allow primary fermentations to occur at $14^{\circ} \mathrm{C}$ (a total of 48 base wines). After the first fermentation, the wines were racked, $50 \mathrm{mg} / \mathrm{L} \mathrm{SO}_{2}$ was added and base wine samples were taken for routine and organic acid analysis. Bentonite $(0.75 \mathrm{~g} / \mathrm{L})$ was added to the wines for clarification, and they were then cold stabilised at $0^{\circ} \mathrm{C}$ for two weeks. After cold stabilisation, the Chardonnay and Pinot noir wines were reracked, blended (50/50 ratio) and sampled for organic acid analysis. The blended wines were sweetened to $24 \mathrm{~g} / \mathrm{L}$ with sucrose (cane sugar), inoculated with $4 \%$ tirage liqueur of the same $S$. cerevisiae IOC182007 yeast, and then bottled under inert gas (nitrogen) with a crown capper. Pressure tests were conducted for nine months to monitor the horizontally shelved bottle fermentations. Once secondary fermentation reached completion, the wines were riddled, re-capped and disgorged at Simonsig Cellar, Stellenbosch, South Africa. Samples were also collected for organic acid analysis and there was no addition of Liqueur d'expédition/Liqueur de dosage at this stage.

\section{Oenological variables}

The sugar content of the free-run juices of grapes subjected to different temperature treatments was analysed using a refractometer (PR-30 $\alpha$ Atago, Palette). Titratable acidity (TA) and $\mathrm{pH}$ were analysed using American Chemical Society (ACS)-grade reagents (Hanna Instruments (Pty) Ltd, USA) on a Tim868 auto-titrator. $\mathrm{SO}_{2}$ concentrations were monitored throughout the MCC production stages using the Ripper method (Vahl \& Converse, 1980). Volatile acidity (VA) and residual sugars (RS) were analysed at Koelenhof laboratory (Koelenhof, South Africa) using distillation and Fehlings tests respectively. An Anton Paar alcoholiser was used to analyse the alcohol levels of the wines.

\section{Organic acid analysis}

MCC wine samples were filtered through $0.45 \mu \mathrm{M}$ nylon membranes and analysed by an enzyme robot (Arena 20XT, Thermo Electron, Finland) using a Megazyme pyruvic acid kit (Megazyme International, Ireland) for pyruvic acid quantification. Citric, malic and succinic acid kits (Megazyme International, Ireland) were used for the quantification of these acids. NADH consumption was monitored spectrophotometrically by measuring the decrease in absorbance at $340 \mathrm{~nm}$.

\section{Data analysis}

The trends within various sets of data were investigated by principal component analysis (PCA; Latentix 2.0, Brandon Gray Internet Services, Inc. dba). The PCA data was transformed using the auto-scale function and the PCA models were calculated. The trends and variables considered at different sampling points were as a result of changes in the organic acid levels (citric, malic, succinic and pyruvic acid) of the wines (Chardonnay and Pinot noir) originating from the farms in the Robertson and Elgin regions. To determine whether there were significant differences in the oenological properties of the samples, the analysis of variance was performed using the GLM (General Linear Models) procedure of SAS software (Version 9.4; SAS Institute Inc, Cary, NC, USA). The Shapiro-Wilk test was performed to test for normality (Shapiro \& Wilk, 1965). Fisher's least significant difference was calculated at the $5 \%$ level to compare treatment means (Ott, 1998), and a probability level of $5 \%$ was considered significant for all significance tests.

\section{RESULTS AND DISCUSSION}

\section{Oenological characteristics}

Although the main focus of the current study was on the relationship between grape temperature and the organic acid profiles of MCC wines, it was also crucial to establish any interplay between grape temperature and the oenological characteristics (volatile acidity, alcohol levels, titratable acidity, $\mathrm{pH}$ and residual sugars) of the juices, base, blended and post-tirage wines, as these also play an important role 
in wine characterisation and differentiation. While several studies have shown that the oenological characteristics of wines are regional (Oliveira et al., 2005; Gil et al., 2006; Louw, 2009; Vilanova et al., 2010) and cultivar (Câmara et al., 2006; Weldegergis et al., 2011) dependent, our study revealed additive influences of grape temperature. Subsequent to temperature treatments, our study observed slight variations in the sugar content of the free-run juices for the Robertson and Elgin cultivars (Table 1).

Several other authors have also showed how frozen grapes (before pressing) have an impact on the sensory and chemical profiles of ice wines (Cliff et al., 2002; Erasmus et al., 2004; Cliff \& Pickering, 2006; Pigeau et al., 2007; Bowen et al., 2012). In this study, some noteworthy outcomes were revealed when the oenological assessment of grapes and wines from different regions and cultivars was done during winemaking. Regardless of the variations in grape temperature, both the Robertson and Elgin base wines fermented to dryness (residual sugars $<5 \mathrm{~g} / \mathrm{L}$ ). $\mathrm{pH}$ and TA across all production stages and temperature treatments varied between 3.03 and $3.75 \mathrm{~g} / \mathrm{L}$ and 5.98 and $9.07 \mathrm{~g} / \mathrm{L}$ for Robertson wines respectively, and 2.82 to $3.44 \mathrm{~g} / \mathrm{L}$ and 8.85 and $11.88 \mathrm{~g} / \mathrm{L}$ for Elgin wines respectively (Tables 2 and 3). Previously, an interplay between climatic areas and $\mathrm{pH}$ variations was also demonstrated in ice wines (DobrowolskaIwanek et al., 2014). In the latter case, the authors reported a significant variation in the $\mathrm{pH}$ of red wines, ranging from
$3.43 \pm 0.01$ (Rondo) to $3.61 \pm 0.01$ (Maréchal Foch), and in white wines it ranged from $3.14 \pm 0.04$ (Sibera) to $3.33 \pm$ 0.01 (Aurora). As in the current study, although these were wines of cold-climate areas, significant $\mathrm{pH}$ variations were noted, in addition to climatic/regional differences. However, the generally low $\mathrm{pH}$ ranges observed in our study were considered very essential for microbial stability during/after fermentation (De Orduña, 2010; Benucci et al., 2016).

Some similar trends were observed between wines from the Robertson and Elgin regions. Volatile and titratable acidity, $\mathrm{pH}$ and the alcohol of the base wines (both Chardonnay and Pinot noir) were not significantly affected by variations in grape temperature (Tables 2 and 3). Minnaar and Booyse (2004) also could not differentiate wines by assessing oenological variables such as $\mathrm{pH}$, ethanol and volatile acid for three different areas in the Western Cape. The final volatile acidity of the post-tirage wines was grape temperature dependent in both regions, wherein a significantly lower volatile acidity was observed in wines that were vinified from grapes at lower temperature treatments $\left(0^{\circ} \mathrm{C}\right.$ and $\left.10^{\circ} \mathrm{C}\right)$. A significant difference between the volatile acidity of wines has also been reported in the past (Shellie, 2007; Stratil et al., 2008; Leja et al., 2011), and volatile compounds can be used to differentiate between different wine origins (Gil et al., 2006; Vilanova et al., 2010). Grape temperature was mostly responsible for the significantly higher $\mathrm{pH}$ of Robertson (Table 2) and lower $\mathrm{pH}\left(0^{\circ} \mathrm{C}\right)$ of

TABLE 1

Oenological characteristics of free-run juices extracted from the grapes sourced from Robertson and Elgin.

\begin{tabular}{|c|c|c|c|}
\hline Treatments & pH & TA (g/L) & ${ }^{\circ}$ Brix \\
\hline \multicolumn{4}{|l|}{ Robertson } \\
\hline $\mathrm{CH}\left(0^{\circ} \mathrm{C}\right)$ & $3.18^{b} \pm 0.036$ & $9.07^{a} \pm 0.358$ & $19.73^{b} \pm 0.115$ \\
\hline $\mathrm{CH}\left(10^{\circ} \mathrm{C}\right)$ & $3.22^{\mathrm{ab}} \pm 0.021$ & $7.33^{b} \pm 0.315$ & $20.57^{a} \pm 0.153$ \\
\hline $\mathrm{CH}\left(25^{\circ} \mathrm{C}\right)$ & $3.31^{\mathrm{a}} \pm 0.006$ & $7.87^{b} \pm 0.115$ & $19.57^{b} \pm 0.208$ \\
\hline $\mathrm{CH}\left(30^{\circ} \mathrm{C}\right)$ & $3.30^{\mathrm{a}} \pm 0.104$ & $8.13^{\mathrm{ab}} \pm 0.153$ & $19.27^{\mathrm{c}} \pm 0.115$ \\
\hline $\mathrm{PN}\left(0^{\circ} \mathrm{C}\right)$ & $3.49^{b} \pm 0.029$ & $7.13^{b} \pm 0.551$ & $20.13^{a} \pm 0.153$ \\
\hline $\mathrm{PN}\left(10^{\circ} \mathrm{C}\right)$ & $3.42^{b} \pm 0.119$ & $5.98^{c} \pm 0.154$ & $19.50^{b} \pm 0.173$ \\
\hline $\mathrm{PN}\left(25^{\circ} \mathrm{C}\right)$ & $3.23^{c} \pm 0.012$ & $9.02^{a} \pm 0.111$ & $18.07^{d} \pm 0.153$ \\
\hline $\mathrm{PN}\left(30^{\circ} \mathrm{C}\right)$ & $3.26^{c} \pm 0.021$ & $7.73^{b} \pm 0.252$ & $18.63^{c} \pm 0.252$ \\
\hline \multicolumn{4}{|l|}{ Elgin } \\
\hline $\mathrm{CH}\left(0^{\circ} \mathrm{C}\right)$ & $3.18^{\mathrm{a}} \pm 0.036$ & $10.14 .0^{\mathrm{a}} \pm 0.347$ & $19.73^{a} \pm 0.115$ \\
\hline $\mathrm{CH}\left(10^{\circ} \mathrm{C}\right)$ & $3.08^{a} \pm 0.031$ & $9.33^{b} \pm 0.252$ & $18.53^{a} \pm 0.379$ \\
\hline $\mathrm{CH}\left(25^{\circ} \mathrm{C}\right)$ & $3.11^{\mathrm{a}} \pm 0.031$ & $10.47^{\mathrm{a}} \pm 0.224$ & $18.60^{\mathrm{a}} \pm 0.173$ \\
\hline $\mathrm{CH}\left(30^{\circ} \mathrm{C}\right)$ & $2.92^{\mathrm{b}} \pm 0.021$ & $9.90^{\mathrm{ab}} \pm 0.421$ & $18.13^{a} \pm 0.902$ \\
\hline $\mathrm{PN}\left(0^{\circ} \mathrm{C}\right)$ & $3.23^{a} \pm 0.010$ & $10.37^{b} \pm 0.231$ & $18.90^{a} \pm 0.520$ \\
\hline $\mathrm{PN}\left(10^{\circ} \mathrm{C}\right)$ & $2.91^{d} \pm 0.044$ & $11.13^{a} \pm 0.058$ & $18.63^{a} \pm 0.252$ \\
\hline $\mathrm{PN}\left(25^{\circ} \mathrm{C}\right)$ & $3.01^{c} \pm 0.006$ & $11.03^{a} \pm 0.072$ & $17.17^{b} \pm 0.321$ \\
\hline $\mathrm{PN}\left(30^{\circ} \mathrm{C}\right)$ & $3.09^{b} \pm 0.035$ & $10.53^{b} \pm 0.306$ & $18.43^{a} \pm 0.153$ \\
\hline
\end{tabular}

The values in the table are means and standard deviations. Different superscript letters and italicised superscript letters in a column represent statistically significant differences $(p<0.05)$ in grape temperature for Chardonnay $(C H)$ and Pinot noir $(P N)$ free-run juices respectively. Means that do not have a common superscript differ significantly. 
TABLE 2

Oenological characteristics of the wines vinified from the grapes sourced from Robertson.

\begin{tabular}{|c|c|c|c|c|c|}
\hline Sample & pH & TA (g/L) & VA $(g / L)$ & RS (g/L) & Alcohol (\%v/v) \\
\hline \multicolumn{6}{|l|}{ Base } \\
\hline $\mathrm{CH}\left(0^{\circ} \mathrm{C}\right)$ & $\begin{array}{l}3.11^{\mathrm{a}} \\
\pm 0.013\end{array}$ & $\begin{array}{l}8.53^{\mathrm{a}} \\
\pm 0.305\end{array}$ & $\begin{array}{l}0.24^{\mathrm{a}} \\
\pm 0.058\end{array}$ & $\begin{array}{l}2.02^{\mathrm{a}} \\
\pm 0.156\end{array}$ & $\begin{array}{l}11.61^{\mathrm{b}} \\
\pm 0.006\end{array}$ \\
\hline $\mathrm{CH}\left(10^{\circ} \mathrm{C}\right)$ & $\begin{array}{l}3.10^{\mathrm{a}} \\
\pm 0.013\end{array}$ & $\begin{array}{l}8.34^{\mathrm{a}} \\
\pm 0.147\end{array}$ & $\begin{array}{l}0.28^{\mathrm{a}} \\
\pm 0.036\end{array}$ & $\begin{array}{l}2.10^{\mathrm{a}} \\
\pm 0.212\end{array}$ & $\begin{array}{l}11.95^{\mathrm{a}} \\
\pm 0.127\end{array}$ \\
\hline $\mathrm{CH}\left(25^{\circ} \mathrm{C}\right)$ & $\begin{array}{l}3.03^{\mathrm{a}} \\
\pm 0.177\end{array}$ & $\begin{array}{l}8.69^{a} \\
\pm 0.228\end{array}$ & $\begin{array}{l}0.23^{\mathrm{a}} \\
\pm 0.051\end{array}$ & $\begin{array}{l}1.87^{\mathrm{a}} \\
\pm 0.201\end{array}$ & $\begin{array}{l}11.34^{\mathrm{b}} \\
\pm 0.323\end{array}$ \\
\hline $\mathrm{CH}\left(30^{\circ} \mathrm{C}\right)$ & $\begin{array}{l}3.15^{\mathrm{a}} \\
\pm 0.036\end{array}$ & $\begin{array}{l}8.31^{\mathrm{a}} \\
\pm 0.180\end{array}$ & $\begin{array}{l}0.30^{\mathrm{a}} \\
\pm 0.012\end{array}$ & $\begin{array}{l}1.80^{\mathrm{a}} \\
\pm 0.255\end{array}$ & $\begin{array}{l}11.41^{\mathrm{b}} \\
\pm 0.052\end{array}$ \\
\hline $\mathrm{PN}\left(0^{\circ} \mathrm{C}\right)$ & $\begin{array}{l}3.11^{a b} \\
\pm 0.077\end{array}$ & $\begin{array}{l}7.63^{b} \\
\pm 0.284\end{array}$ & $\begin{array}{l}0.33^{a} \\
\pm 0.055\end{array}$ & $\begin{array}{l}1.83^{a} \\
\pm 0.430\end{array}$ & $\begin{array}{l}12.04^{a} \\
\pm 0.47\end{array}$ \\
\hline $\mathrm{PN}\left(10^{\circ} \mathrm{C}\right)$ & $\begin{array}{l}3.15^{a} \\
\pm 0.046\end{array}$ & $\begin{array}{l}6.96^{b} \\
\pm 0.467\end{array}$ & $\begin{array}{l}0.39^{a} \\
\pm 0.020\end{array}$ & $\begin{array}{l}1.41^{a} \\
\pm 0.177\end{array}$ & $\begin{array}{l}11.17^{a b} \\
\pm 0.777\end{array}$ \\
\hline $\mathrm{PN}\left(25^{\circ} \mathrm{C}\right)$ & $\begin{array}{l}3.03^{b} \\
\pm 0.043\end{array}$ & $\begin{array}{l}9.05^{a} \\
\pm 0.454\end{array}$ & $\begin{array}{l}0.41^{a} \\
\pm 0.078\end{array}$ & $\begin{array}{l}1.62^{a} \\
\pm 0.668\end{array}$ & $\begin{array}{l}10.56^{b} \pm \\
0.078\end{array}$ \\
\hline $\mathrm{PN}\left(30^{\circ} \mathrm{C}\right)$ & $\begin{array}{l}3.10^{a b} \\
\pm 0.071\end{array}$ & $\begin{array}{l}7.53^{b} \\
\pm 0.207\end{array}$ & $\begin{array}{l}0.37^{a} \\
\pm 0.044\end{array}$ & $\begin{array}{l}1.55^{a} \\
\pm 0.312\end{array}$ & $\begin{array}{l}11.30^{a b} \\
\pm 0.384\end{array}$ \\
\hline \multicolumn{6}{|l|}{ Blends } \\
\hline $0^{\circ} \mathrm{C}$ & $\begin{array}{l}3.18^{\mathrm{cB}} \\
\pm 0.053\end{array}$ & $\begin{array}{l}7.62^{\mathrm{bB}} \\
\pm 0.296\end{array}$ & $\begin{array}{l}0.44^{\mathrm{c} \mathrm{BC}} \\
\pm 0.025\end{array}$ & $\begin{array}{l}1.04^{\mathrm{c} \mathrm{B}} \\
\pm 0.040\end{array}$ & $\begin{array}{l}11.71^{\mathrm{a} \mathrm{BC}} \\
\pm 0.235\end{array}$ \\
\hline $10^{\circ} \mathrm{C}$ & $\begin{array}{l}3.29^{\mathrm{ab} \mathrm{B}} \\
\pm 0.037\end{array}$ & $\begin{array}{l}7.21^{\mathrm{bBC}} \\
\pm 0.387\end{array}$ & $\begin{array}{l}0.57^{\mathrm{a} \mathrm{B}} \\
\pm 0.040\end{array}$ & $\begin{array}{l}1.22^{\mathrm{bB}} \\
\pm 0.133\end{array}$ & $\begin{array}{l}11.65^{\mathrm{a} C D} \\
\pm 0.085\end{array}$ \\
\hline $25^{\circ} \mathrm{C}$ & $\begin{array}{l}3.24^{\mathrm{bc} \mathrm{B}} \\
\pm 0.009\end{array}$ & $\begin{array}{l}8.45^{\mathrm{aA}} \\
\pm 0.555\end{array}$ & $\begin{array}{l}0.51^{\mathrm{bA}} \\
\pm 0.01\end{array}$ & $\begin{array}{l}1.43^{\mathrm{aA}} \\
\pm 0.086\end{array}$ & $\begin{array}{l}10.98^{\mathrm{cE}} \\
\pm 0.119\end{array}$ \\
\hline $30^{\circ} \mathrm{C}$ & $\begin{array}{l}3.31^{\mathrm{a} \mathrm{B}} \\
\pm 0.029\end{array}$ & $\begin{array}{l}7.16^{\mathrm{bBC}} \\
\pm 0.042\end{array}$ & $\begin{array}{l}0.51^{\mathrm{bB}} \\
\pm 0.015\end{array}$ & $\begin{array}{l}1.50^{\mathrm{a} \text { B }} \\
\pm 0.011\end{array}$ & $\begin{array}{l}11.33^{\mathrm{b} D E} \\
\pm 0.157\end{array}$ \\
\hline \multicolumn{6}{|l|}{$M C C$} \\
\hline $0^{\circ} \mathrm{C}$ & $\begin{array}{l}3.69^{\mathrm{aA}} \\
\pm 0.052\end{array}$ & $\begin{array}{l}7.52^{\mathrm{a} \mathrm{B}} \\
\pm 0.278\end{array}$ & $\begin{array}{l}0.08^{\mathrm{bE}} \\
\pm 0.010\end{array}$ & $\begin{array}{l}1.15^{\mathrm{a} \mathrm{B}} \\
\pm 0.046\end{array}$ & $\begin{array}{l}12.47^{\mathrm{a} \mathrm{A}} \\
\pm 0.411\end{array}$ \\
\hline $10^{\circ} \mathrm{C}$ & $\begin{array}{l}3.75^{\mathrm{aA}} \\
\pm 0.154\end{array}$ & $\begin{array}{l}6.47^{\mathrm{bc}} \\
\pm 0.655\end{array}$ & $\begin{array}{l}0.26^{\mathrm{bD}} \\
\pm 0.085\end{array}$ & $\begin{array}{l}1.07^{\mathrm{ab} \mathrm{B}} \\
\pm 0.084\end{array}$ & $\begin{array}{l}12.07^{\mathrm{a} \mathrm{B}} \\
\pm 0.144\end{array}$ \\
\hline $25^{\circ} \mathrm{C}$ & $\begin{array}{l}3.34^{\text {b в }} \\
\pm 0.225\end{array}$ & $\begin{array}{l}7.67^{\mathrm{aAB}} \\
\pm 0.448\end{array}$ & $\begin{array}{l}0.83^{\mathrm{aA}} \\
\pm 0.201\end{array}$ & $\begin{array}{l}1.01^{\mathrm{b} \mathrm{B}} \\
\pm 0.017\end{array}$ & $\begin{array}{l}11.30^{\mathrm{b} D E} \\
\pm 0.262\end{array}$ \\
\hline $30^{\circ} \mathrm{C}$ & $\begin{array}{l}3.26^{\mathrm{b} \mathrm{B}} \\
\pm 0.032\end{array}$ & $\begin{array}{l}7.19^{\mathrm{ab} \mathrm{BC}} \\
\pm 0.696\end{array}$ & $\begin{array}{l}0.28^{\mathrm{bCD}} \\
\pm 0.015\end{array}$ & $\begin{array}{l}1.07^{\mathrm{ab} \mathrm{B}} \\
\pm 0.038\end{array}$ & $\begin{array}{l}12.00^{\mathrm{a} B C} \\
\pm 0.128\end{array}$ \\
\hline
\end{tabular}

The values in the table are means and standard deviations. Different superscript letters in a column represent statistically significant differences $(p<0.05)$ in grape temperature for Chardonnay $(\mathrm{CH})$ base, Pinot noir $(P N)$ base, blended and post-tirage wines. Different italicised superscript letters in a column represent statistically significant differences $(p<0.05)$ in grape temperature for Pinot noir base wines. Uppercase superscript letters in a column represent a statistically significant differences in grape temperature at different production stages. Means that do not have a common superscript differ significantly

Elgin post-tirage wines (Table 3). Lower $\mathrm{pH}$ values have also been reported in Riesling ice wines that were vinified from grapes that were harvested at $\leq-8^{\circ} \mathrm{C}$ and pressed at a lower temperature (Nurgel et al., 2004).

While alcohol levels in the post-tirage wines (also known as post-secondary fermentation or final MCC wines) were relatively higher than at the blending stages for both regions (Tables 1 and 2), a stage-wise comparison between the blended base wines and post-tirage wines further displayed a significant decrease in titratable acidity (Table 3 ) and increase in $\mathrm{pH}$ (Tables 2 and 3) MCC wines. Several other studies have also reported a direct relationship between secondary fermentation and alcohol formation in sparkling wines (Torresi et al., 2011; Benucci et al., 2016).

The impact of grape temperature on organic acid levels While the most commonly measured features of wine acidity are titratable acidity and $\mathrm{pH}$, most organic acids are important markers for fermentation management, and for wine flavour and aroma (Tita et al., 2006; Apichai et al., 2007). The impact 
of grape temperature at pressing on the organic acid profiles of base wines from different regions was also assessed in the current study. Fig. 1 shows the principal component analysis (PCA), illustrating such influences on Chardonnay (A) and Pinot noir (B) base wines. In both cases, sample grouping of grape temperature treatments were observed for both origins.

Some similarities in the organic acid trends of the base wines were identified for both regions (Robertson and Elgin). Cultivar-dependent differences were also observed when lower grape temperatures $\left(0^{\circ} \mathrm{C}\right.$ and $\left.10^{\circ} \mathrm{C}\right)$ were responsible for higher succinic and malic acid concentrations in Chardonnay wines that were vinified from Robertson and Elgin grapes (Fig. 1A), while Pinot noir wines were characterised by higher levels of pyruvic, succinic, malic and citric acids (Fig. 1B). Dobrowolska-Iwanek et al. (2014) also reported relatively higher malic and succinic acid concentrations in Seyval Blanc and Marechal Foch cultivars from cool climate areas in South Poland. However, compared to other white cultivars, relatively higher malic acid contents of Chardonnay wines have been reported (Coulter et al., 2004). Interestingly, higher succinic and malic acid concentrations were common in all the wines (both Chardonnay and Pinot noir) that were vinified from lower temperature-treated grapes from both regions, but malic acid was more pronounced in the Elgin wines (Fig. 1A). While information on the impact of grape storage temperature on the organic acid levels of the wines is still lacking, higher malic acids concentrations in the wines were expected from cooler regions, which are characterised by slower malic acid degradation/respiration rates (e.g. Elgin) (Darias-Martin et al., 2000; Volschenk et al., 2006). In this case, malic acid extractability during pressing seemed to be highly promoted at conditions of lower grape storage temperature. On the other hand, it is still unclear how lower temperature treatments resulted in the higher succinic acid concentrations of the Chardonnay white wines from both regions (Fig. 1A). In the current study, succinic acid concentrations were affected insignificantly in the red cultivars (Pinot noir) (Fig. 1B), but this was not surprising since grape variety is known to have a minimal impact on succinic acid production in red wines (Coulter et al., 2004). It is also plausible that variations in the nutritional composition of the juice occurred after grape pressing, and this might have affected yeast succinic acid metabolism.

In the current study, citric acid analysis was crucial since it is characterised by the sensorial features of 'freshness'

A

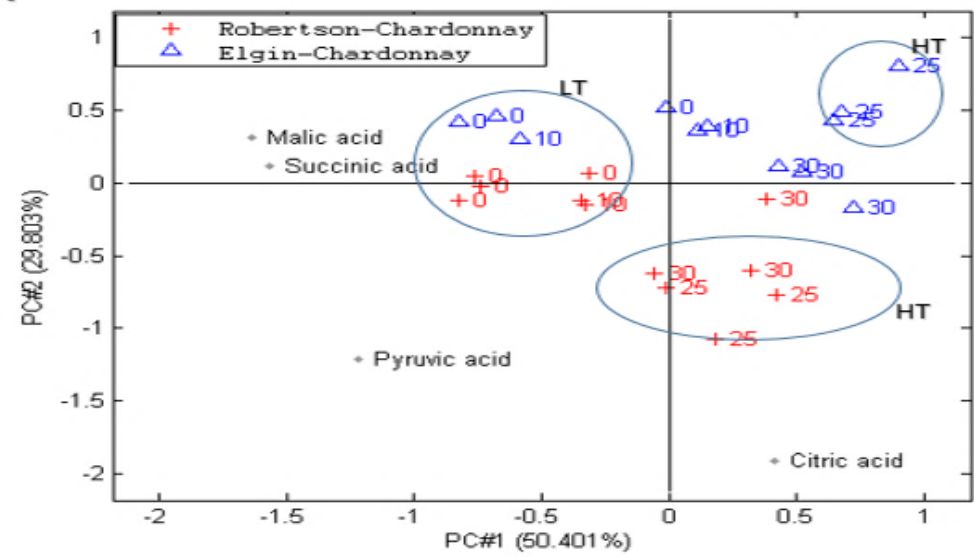

B

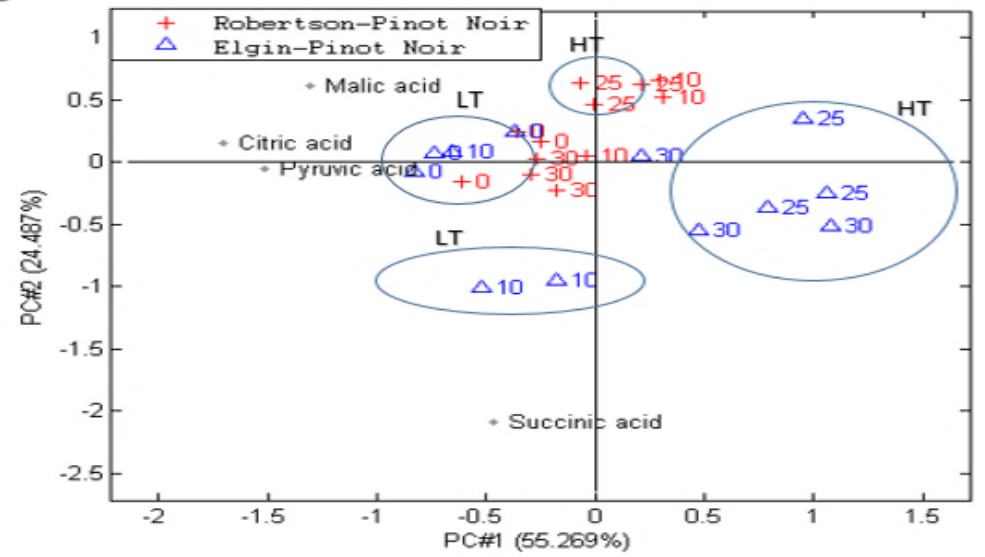

FIGURE 1

The PCA bi-plot showing the impact of grape temperature on the organic acid profiles of Chardonnay (A) and Pinot noir (B) base wines from different regions (Robertson and Elgin). Fermentations were carried out in triplicate. (LT) lower temperature $=0^{\circ} \mathrm{C}$ and $/$ or $10^{\circ} \mathrm{C},(\mathrm{HT})$ higher temperature $=25^{\circ} \mathrm{C}$ and $/$ or $30^{\circ} \mathrm{C}$. 
associated with well-balanced citric acid levels (Kalathenos et al., 1995). Citric acid was one of the distinctive features between Robertson and Elgin. This acid was only pronounced in Chardonnay wines that were vinified from conditions of higher grape temperatures $\left(25^{\circ} \mathrm{C}\right.$ and $\left.30^{\circ} \mathrm{C}\right)$ in Robertson (Fig. 1A). Based on this observation, the study shows that citric acid extractability during grape pressing is dependent on grape temperature and cultivar. While is it unclear how grape temperature affects citric acid extraction during pressing, citric acid recovery from apples is also promoted at a relatively higher temperature $\left(50^{\circ} \mathrm{C}\right)$ (Blanco et al., 1996). Similarly, García-Romero et al. (1993) also highlighted the importance of environmental conditions and grape cultivar in relation to acids such as citric acid. Unlike malic acid, citric acid extraction during the pressing of Chardonnay grapes (Fig. 1A) was promoted at a higher temperature (HT), while Pinot noir (Fig. 1B) grapes treated at a higher temperature were rich in citric acid in both regions. These findings show how cultivar differences significantly affect the grape-derived acid concentrations of the final wines, although insignificant regional influences were observed. The study therefore concludes that citric acid extraction/ recovery and grape temperature are obviously two different phenomena that influence each other in a very complicated manner.

Previous reports have also highlighted the importance of citric acid to organoleptic properties as well as yeast growth rate during alcoholic fermentation (Nielsen \& Arneborg, 2007). Although organic acid levels have been reported to be region and cultivar dependent (Ribéreau-Gayon, 2006; Shellie, 2007; Willershausen et al., 2009; Tarko et al., 2010), the management of grape temperature at pressing can be an alternative tool for acidity management of the wines.

The impact of grape temperature on organic acid levels at different production stages

The impact of grape temperature on the acid profiles at different stages of MCC production was also assessed for both regions (Fig. 2). Distinct clusters of groups for different temperature treatments of the blended and post-tirage wines

A

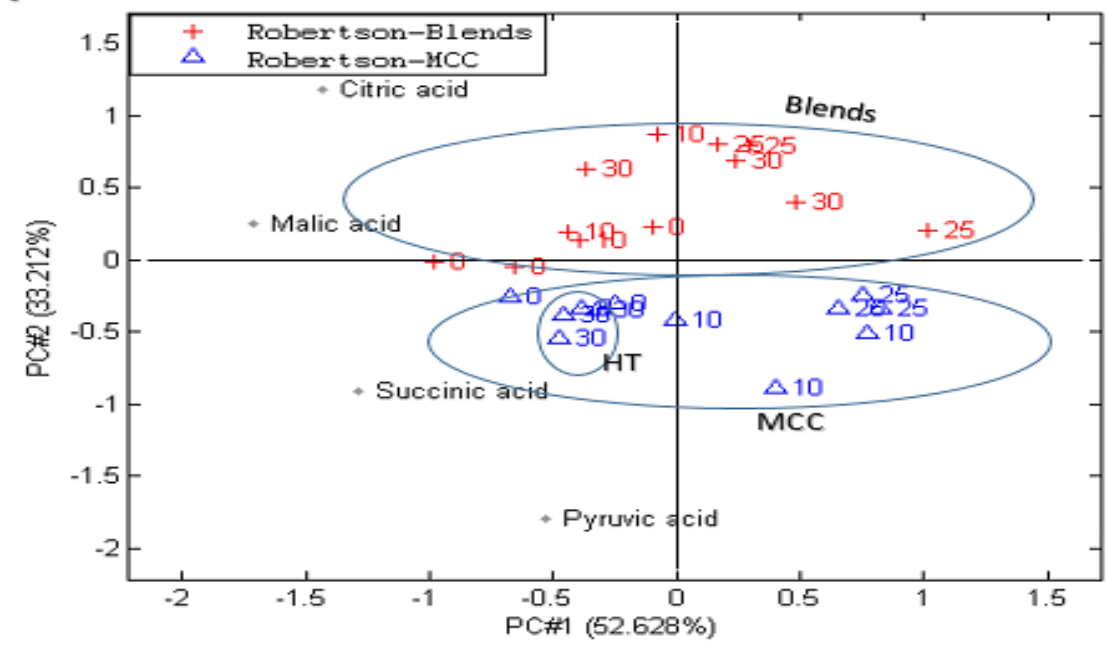

B

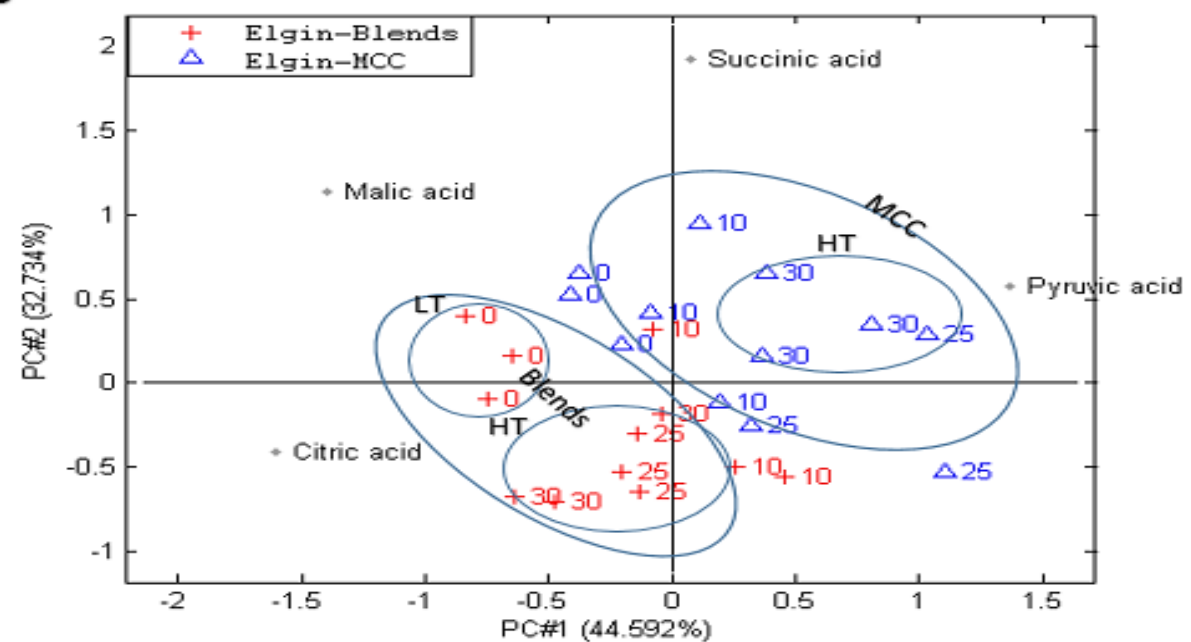

FIGURE 2

The PCA bi-plot showing the influence of grape temperature on the organic acid characteristics of wines (blended vs. posttirage production stage) vinified from Robertson (A) and Elgin (B) grapes. Fermentations were carried out in triplicate. (LT) lower temperature $=0{ }^{\circ} \mathrm{C}$ and $/$ or $10^{\circ} \mathrm{C},(\mathrm{HT})$ higher temperature $=25^{\circ} \mathrm{C}$ and $/$ or $30^{\circ} \mathrm{C}$. 
were observed for the Robertson (Fig. 2A) and Elgin (Fig. 2B) production regions. The Robertson blended wines were richer in citric acid in the lower temperature treatments $\left(0^{\circ} \mathrm{C}\right.$ and $10^{\circ} \mathrm{C}$ ), whereas pyruvic and succinic acid dominated the post-tirage samples in the $0^{\circ} \mathrm{C}$ and $30^{\circ} \mathrm{C}$ treatments (see Fig. 2A). This is not surprising, since the increase in pyruvic and succinic acid was a resultant of secondary alcoholic fermentation. However, it was uncertain how grape temperature conditions affected the concentrations of these fermentation-derived acids. Perhaps the temperature of the grape during pressing affects the nutritional extractability, which automatically affects organic acid metabolism in the yeast (Chidi et al., 2015 ). Except for the $0^{\circ} \mathrm{C}$ treatments, less malic acid features were observed in the post-tirage wines from both regions (Fig. 2A and 2B). While most commercial wine yeast strains are incapable of degrading malic acid during alcoholic fermentation, fermentation conditions may have promoted the proliferation of naturally occurring lactic acid bacteria (LAB), which resulted in malic acid consumption during the secondary alcoholic fermentation (Lambrechts \& Pretorius, 2000). Alternatively, malic acid decline could have resulted from enzyme-catalysed reactions, salt precipitation and oxidation-reduction reactions during ageing (Amerine et al., 1979).

On the other hand, the blended wines from Robertson (Fig. 2A) and Elgin (Fig. 2B) were higher in citric and malic

TABLE 3

Oenological characteristics of the wines vinified from the grapes sourced from Elgin.

\begin{tabular}{|c|c|c|c|c|c|}
\hline Sample & pH & TA (g/L) & VA (g/L) & $R S(g / L)$ & $\operatorname{Alcohol}(\% \mathrm{v} / \mathrm{v})$ \\
\hline \multicolumn{6}{|l|}{ Base } \\
\hline $\mathrm{CH}\left(0^{\circ} \mathrm{C}\right)$ & $\begin{array}{l}2.87^{\mathrm{c}} \\
\pm 0.012\end{array}$ & $\begin{array}{l}11.15^{\mathrm{a}} \\
\pm 0.259\end{array}$ & $0.07^{\mathrm{a}} \pm 0.040$ & $1.78^{a} \pm 0.646$ & $11.08^{\mathrm{a}} \pm 0.316$ \\
\hline $\mathrm{CH}\left(10^{\circ} \mathrm{C}\right)$ & $\begin{array}{l}2.90^{c} \\
\pm 0.029\end{array}$ & $\begin{array}{l}10.97^{\mathrm{ab}} \\
\pm 0.014\end{array}$ & $0.12^{\mathrm{a}} \pm 0.057$ & $1.70^{b} \pm 0.035$ & $10.15^{\mathrm{a}} \pm 0.516$ \\
\hline $\mathrm{CH}\left(25^{\circ} \mathrm{C}\right)$ & $\begin{array}{l}2.93^{\mathrm{b}} \\
\pm 0.018\end{array}$ & $\begin{array}{l}11.14^{\mathrm{a}} \\
\pm 0.713\end{array}$ & $0.09^{\mathrm{a}} \pm 0.023$ & $1.65^{\mathrm{ab}} \pm 0.098$ & $10.18^{\mathrm{a}} \pm 0.430$ \\
\hline $\mathrm{CH}\left(30^{\circ} \mathrm{C}\right)$ & $\begin{array}{l}2.96^{\mathrm{a}} \\
\pm 0.025\end{array}$ & $\begin{array}{l}10.30^{\mathrm{b}} \\
\pm 0.388\end{array}$ & $0.10^{\mathrm{a}} \pm 0.045$ & $1.05^{\mathrm{b}} \pm 0.029$ & $10.84^{\mathrm{a}} \pm 0.486$ \\
\hline $\mathrm{PN}\left(0^{\circ} \mathrm{C}\right)$ & $\begin{array}{l}2.91^{a} \\
\pm 0.152\end{array}$ & $\begin{array}{l}10.13^{b} \\
\pm 0.060\end{array}$ & $0.22^{a} \pm 0.026$ & $1.54^{\mathrm{a}} \pm 0.240$ & $10.94^{\mathrm{a}} \pm 0.439$ \\
\hline $\mathrm{PN}\left(10^{\circ} \mathrm{C}\right)$ & $\begin{array}{l}2.82^{a} \\
\pm 0.031\end{array}$ & $\begin{array}{l}10.87^{b} \\
\pm 0.045\end{array}$ & $0.22^{a} \pm 0.017$ & $1.82^{a} \pm 0.656$ & $10.78^{a} \pm 0.064$ \\
\hline $\mathrm{PN}\left(25^{\circ} \mathrm{C}\right)$ & $\begin{array}{l}2.89^{a} \\
\pm 0.011\end{array}$ & $\begin{array}{l}11.88^{a} \\
\pm 0.73\end{array}$ & $0.28^{a} \pm 0.102$ & $1.82^{a} \pm 0.316$ & $10.11^{b} \pm 0.365$ \\
\hline $\mathrm{PN}\left(30^{\circ} \mathrm{C}\right)$ & $\begin{array}{l}2.89^{a} \\
\pm 0.032\end{array}$ & $\begin{array}{l}10.48^{b} \\
\pm 0.325\end{array}$ & $0.06^{b} \pm 0.036$ & $1.41^{a} \pm 0.106$ & $10.89^{a} \pm 0.070$ \\
\hline \multicolumn{6}{|l|}{ Blends } \\
\hline $0^{\circ} \mathrm{C}$ & $\begin{array}{l}3.05^{\mathrm{d} D} \\
\pm 0.005\end{array}$ & $\begin{array}{l}10.38^{\mathrm{ab} \mathrm{AB}} \\
\pm 0.223\end{array}$ & $\begin{array}{l}0.50^{\mathrm{c} \mathrm{C}} \\
\pm 0.026\end{array}$ & $1.37^{\mathrm{b} B} \pm 0.115$ & $11.20^{\mathrm{a} B C} \pm 0.212$ \\
\hline $10^{\circ} \mathrm{C}$ & $\begin{array}{l}3.06^{\mathrm{cD}} \\
\pm 0.009\end{array}$ & $\begin{array}{l}10.19^{\mathrm{bc} \mathrm{BC}} \\
\pm 0.072\end{array}$ & $\begin{array}{l}0.53^{\mathrm{bc} \mathrm{c}} \\
\pm 0.085\end{array}$ & $1.25^{\mathrm{ab} \mathrm{AB}} \pm 0.158$ & $10.80^{\mathrm{ab} \mathrm{D}} \pm 0.072$ \\
\hline $25^{\circ} \mathrm{C}$ & $\begin{array}{l}3.08^{\mathrm{bCD}} \\
\pm 0.002\end{array}$ & $\begin{array}{l}10.76^{\mathrm{aA}} \\
\pm 0.320\end{array}$ & $\begin{array}{l}0.90^{\mathrm{a} \mathrm{B}} \\
\pm 0.105\end{array}$ & $1.35^{\mathrm{aA}} \pm 0.175$ & $10.46^{\mathrm{bE}} \pm 0.244$ \\
\hline $30^{\circ} \mathrm{C}$ & $\begin{array}{l}3.11^{\mathrm{aC}} \\
\pm 0.005\end{array}$ & $\begin{array}{l}9.88^{\mathrm{c} \mathrm{CD}} \\
\pm 0.124\end{array}$ & $\begin{array}{l}0.66^{\mathrm{bC}} \\
\pm 0.047\end{array}$ & $1.60^{\mathrm{ab} \mathrm{B}} \pm 0.160$ & $10.93^{\mathrm{abCD}} \pm 0.200$ \\
\hline \multicolumn{6}{|l|}{$M C C$} \\
\hline $0^{\circ} \mathrm{C}$ & $\begin{array}{l}3.34^{\mathrm{c} \mathrm{B}} \\
\pm 0.059\end{array}$ & $\begin{array}{l}10.1^{\mathrm{aBC}} \\
\pm 0.151\end{array}$ & $\begin{array}{l}0.08^{\mathrm{cD}} \\
\pm 0.001\end{array}$ & $1.34^{\mathrm{bc} B} \pm 0.106$ & $11.62^{\mathrm{a} \mathrm{A}} \pm 0.182$ \\
\hline $10^{\circ} \mathrm{C}$ & $\begin{array}{l}3.37^{\mathrm{bc} \mathrm{B}} \\
\pm 0.012\end{array}$ & $\begin{array}{l}8.85^{\mathrm{c} \mathrm{F}} \\
\pm 0.216\end{array}$ & $\begin{array}{l}0.14^{\mathrm{cD}} \\
\pm 0.017\end{array}$ & $1.06^{\mathrm{c} B} \pm 0.053$ & $11.41^{\mathrm{ab} \mathrm{AB}} \pm 0.142$ \\
\hline $25^{\circ} \mathrm{C}$ & $\begin{array}{l}3.44^{\mathrm{aA}} \\
\pm 0.035\end{array}$ & $\begin{array}{l}9.31^{\mathrm{bc} \mathrm{EF}} \\
\pm 0.562\end{array}$ & $\begin{array}{l}1.23^{\mathrm{aA}} \\
\pm 0.275\end{array}$ & $1.24^{\mathrm{a} B} \pm 0.173$ & $11.10^{\mathrm{b} B C D} \pm 0.180$ \\
\hline $30^{\circ} \mathrm{C}$ & $\begin{array}{l}3.43^{\mathrm{ab} \mathrm{A}} \\
\pm 0.015\end{array}$ & $\begin{array}{l}9.47^{\mathrm{bDE}} \\
\pm 0.185\end{array}$ & $\begin{array}{l}0.48^{\mathrm{bC}} \\
\pm 0.076\end{array}$ & $1.73^{\mathrm{b} \mathrm{B}} \pm 0.252$ & $11.42^{\mathrm{ab} \mathrm{AB}} \pm 0.246$ \\
\hline
\end{tabular}

The values in the table are means and standard deviations. Different superscript letters in a column represent statistically significant differences $(p<0.05)$ in grape temperature for Chardonnay $(\mathrm{CH})$ base, Pinot noir (PN) base, blended (blends) and post-tirage (MCC) wines. Different italicised superscript letters in a column represent statistically significant differences $(p<0.05)$ in grape temperature for Pinot noir base wines. Uppercase superscript letters in a column represent statistically significant differences in grape temperature at different production stages. Means that do not have a common superscript differ significantly. 
TABLE 4

Pyruvic acid levels of the post-tirage wines vinified from temperature treated grapes originating from Robertson and Elgin.

\begin{tabular}{lcc}
\hline & \multicolumn{2}{c}{ Pyruvic acid (mg/L) } \\
\cline { 2 - 3 } Temperature treatments & Robertson & Elgin \\
\hline $0^{\circ} \mathrm{C}$ & $34.05 \pm 3.334$ & $0.00 \pm 0.000$ \\
$10^{\circ} \mathrm{C}$ & $25.47 \pm 2.251$ & $3.89 \pm 2.705$ \\
$25^{\circ} \mathrm{C}$ & $0.00 \pm 0.000$ & $0.00 \pm 0.000$ \\
$30^{\circ} \mathrm{C}$ & $28.28 \pm 2.803$ & $13.60 \pm 1.945$ \\
\hline
\end{tabular}

Results are the average of three biological repeats \pm standard deviations

acid concentrations (Fig. 2B), while the post-tirage wines had more features of pyruvic and succinic acid. The production of pyruvic and succinic acid was probable at this stage, since they are among the major acids produced by yeast during fermentation (Ribéreau-Gayon et al., 2000). However, regional differences did not change any of the organic acid trends of the wines. An in-depth analysis of the effect of grape temperature conditions on the blended and posttirage wines also showed lower grape temperatures $\left(0^{\circ} \mathrm{C}\right)$ having a slightly higher malic acid content than the posttirage wines. It was indeed very important to establish the relationship between grape temperature and the malic acid concentration of the wines, because this acid is important for monitoring the progress of malolactic fermentation in wines (Ribéreau-Gayon et al., 2000). Pyruvic acid, on the other hand, was more pronounced in the post-tirage wines vinified from conditions of high grape temperatures $\left(25^{\circ} \mathrm{C}\right.$ and $30^{\circ} \mathrm{C}$ ) (Fig. 2B). Apart from acids, the accumulation of phenolic compounds during secondary fermentation has also been reported in sparkling red, rosé and white wines (Hialgo et al., 2004).

\section{Pyruvic acid trends}

A comprehensive production stage comparison of the pyruvic acid levels of the wines vinified from temperaturetreated grapes was necessary, since, in terms of its sensory attributes, this acid imparts a slightly sour taste to wine (Usseglio-Tomasset, 1995). Unlike pyruvic acid, a stage-wise comparison of other acids is not reported, since they did not follow any specific pattern. In both regions, pyruvic acid was only detected in the post-tirage wines (Table 4) and, as one of the key metabolites during alcoholic fermentation (Fernie et al., 2004), undetected pyruvic acid was expected in the base and blended wines (end of primary alcoholic fermentation). Previous reports have also shown that pyruvic acid produced early during alcoholic fermentation, but that it is slowly reabsorbed by yeast throughout the rest of fermentation (Ribéreau-Gayon et al., 2006). In Robertson and Elgin, both $10^{\circ} \mathrm{C}$ (lower temperature) and $30^{\circ} \mathrm{C}$ (higher temperature) post-tirage treatments were rich in pyruvic acid (Table 4) - a clear indication that, at this production stage, regional and temperature differences were not the major drivers of the organic acid profiles of the wine. In addition, significantly higher pyruvic acid concentrations $(\sim 34 \mathrm{mg} / \mathrm{L})$ were also detected in the $0^{\circ} \mathrm{C}$ Robertson MCC treatments (Table 4). As explained earlier, the grape temperature before pressing could also have changed the nutritional composition of the juices, eventually leading to some changes in metabolic flux during fermentation.

The levels of pyruvic acid in wine can vary considerably (Usseglio-Tomasset, 1995), and this sudden increase in pyruvic acid in post-tirage/post-secondary fermentation may be attributed to the fact that secondary fermentation and ageing in the bottle are extremely slow (up to two and nine months respectively), and therefore optimal pyruvate reabsorption occurred partially. Higher alcohol levels might have also disrupted pyruvate utilisation by directing metabolic flux away from acetaldehyde and ethanol production during the post-tirage stages. Our study offers a realistic insight into the effect of the interplay between production stages and grape temperature on the acid profiles of MCC wines. There are many other factors that may explain the variations in acid composition of the wines, and future work should focus on understanding those factors. However, the current study is the first to establish some important factors that contribute to the acidity of South African MCC wines. Moreover, from the data presented here, winemakers will have a better understanding of how wine acid management and quality can be controlled.

\section{CONCLUSIONS}

The current study revealed that the grape temperature at pressing influences standard wine variables and organic acids quantitatively, and thus will have an impact on the final MCC quality. The current study also enabled us to categorise wine organic acids according to different MCC production stages. While many other known and unknown factors may significantly affect the organic acid and oenological characteristics of MCC wines, the current study has provided a better understanding of how the manipulation of some existing MCC production strategies can improve the organoleptic and oenological characteristics of the wines.

\section{LITERATURE CITED}

Amerine, M.A., Berg, H.W., Kunkee, R.E., Ough, C.S., Singleton, V.L. \& Webb, A.D., 1979 ( $4^{\text {th }}$ ed). The technology of winemaking. AVI, Westport, CT.

Apichai, S., Pattana, T., Rodjana, B. \& Supalax, S., 2007. Capillary zone electrophoresis of organic acids in beverages. LWT Food Sci. Technol. 40, 1741-1746. 
Benucci, I., Liburdi, K., Cerreti, M. \& Esti, M., 2016. Characterization of active dry wine yeast during starter culture (Pied de Cuve): Preparation for sparkling wine production. J. Food Sci. 81(8), 2015-2020.

Bisson, L.F. \& Walker, G.A., 2015. The microbial dynamics of wine fermentation. In: W. Holzapfel. (ed). Advances in fermented foods and beverages. Elsevier, Amsterdam, pp. 435 - 476.

Blanco, D., Quintanilla, M.E., Mangas, J.J. \& Gutierrez, M.D., 1996. Determination of organic acids in apple juice by capillary liquid chromatography. J. Liq. Chrom. \& Rel. Technol. 19(16), 2615-2621.

Bowen, A.J. \& Reynolds, A.G., 2012. Odor potency of aroma compounds in Riesling and Vidal blanc table wines and icewines by gas chromatographyolfactometry mass spectrometry. J. Agric. Food Chem. 60, 2874-2883.

Câmara, J.S., Alves, M.A. \& Marques, J.C., 2006. Multivariate analysis for the classification and differentiation of Madeira wines according to main grape varieties. Talanta 68, 1512-1521.

Chidi, B.S., Rossouw, D., Buica, A.S. \& Bauer, F.F., 2015. Determining the impact of industrial wine yeast strains on organic acid production under white and red wine-like fermentation conditions. S. Afr. J. Enol. 36(3), 316327.

Cliff, M. \& Pickering, G.J., 2006. Determination of odour detection thresholds for acetic acid and ethyl acetate in ice wine. J. Wine Res. 17, 45-52.

Cliff, M., Yuksel, D., Girard, B. \& King, M., 2002. Characterization of Canadian ice wines by sensory and compositional analyses. Am. J. Enol. Vitic. 53, 46-53.

Coelho, E., Coimbra, M.A., Nogueria, J.M.F. \& Rocha, S.M., 2009. Quantification approach for assessment of sparkling wine volatiles from different soils, ripening stages, and varieties by stir bar sorptive extraction with liquid 1183 desorption. Anal. Chim. Acta 635, 714-221.

Coulter, A.D, Godden, P.W. \& Pretorius, I.S., 2004. Succinic acid - How it is formed, what is its effect on titratable acidity, and what factors influence its concentration in wine? Aust. N.Z. Wine Indust. J. 19(6), 16-25.

Darias-Martin, J.J., Oscar, R., Diaz, E. \& Lamuela-Raventós, R.M., 2000. Effect of skin contact on the antioxidant phenolics in white wine. Food Chem. 71, 483-487.

De Orduña, R.M., 2010. Climate change associated effects on grape and wine quality and production. Food Res. Int. 43, 1844-1855.

Dobrowolska-Iwanek, J., Gąstol, M., Wanat, A., Krośniak, M., Jancik, M., \& Zagrodzki, P., 2014. Wine of cool-climate areas in South Poland. S. Afr. J. Enol. Vitic. 35(1), 1-9.

Erasmus, D.J., Cliff, M. \& Van Vuuren, H.J.J., 2004. Impact of yeast strain on the production of acetic acid, glycerol, and the sensory attributes of icewine. Am. J. Enol. Vitic. 55, 371-378

Fernie, A.R., Carrari, F. \& Sweetlove, L.J., 2004. Respiratory metabolism: Glycolysis, the TCA cycle and mitochondrial electron transport. Curr. Opin. Plant. Biol. 7(3), 254-261.

García-Romero, E., Sánchez-Muñoz, G., Martín-Alvarez, P.J. \& CabezudoIbáñez, M.D., 1993. Determination of organic acids in grape musts, wines and vinegars by high performance liquid chromatography. J. Chrom. A. 655, $111-117$.

Gil, M., Cabellos, J.M., Arroyo, T. \& Prodanov, M., 2006. Characterization of the volatile fraction of young wines from the Denomination of Origin "Vinos de Madrik" (Spain). Anal. Chim. Acta 563, 145-153.

Hialgo, P., Pueyo, E., Pozo-Bayon, M.A., Martinez-Rodriguez, A.J., Martin-Alvarez, P. \& Polo, M.C., 2004. Sensory and analytical study of rose sparkling wines manufactured by second fermentation in the bottle. J. Agric. Food Chem. 52, 6640-6645.
Jones, G. \& Alves, F., 2012. Impact of climate change on wine production: A global overview and regional assessment in the Douro Valley of Portugal. Int. J. Global Warm. 4(3-4), 383-406.

Jones, G.V., White, M.A., Cooper, O.R. \& Storchmann. K., 2005. Climate change and global wine quality. Clim. Change 73(3), 319-343.

Kalathenos, P., Sutherland, J.P. \& Roberts, T.A., 1995. Resistance of some wine spoilage yeasts to combination of ethanol and acids present in wine. J. Appl. Bacteriol. 78, 245-250.

Kornberg, H.L. \& Madsen, N.B., 1958. The metabolism of $\mathrm{C}_{2}$ compounds in microorganisms: Synthesis of malate from acetate via the glyoxylate cycle. Biochem. J. 68, 549-557.

Lambrechts, M.G. \& Pretorius, I.S., 2000. Yeast and its importance in wine aroma - A review. S. Afr. J. Enol. Vitic. 21, 97-129.

Leja, M., Kamińska, I. \& Kulczak, K., 2011. Antioxidative properties in grapes of selected cultivars grown in Poland. Ecol. Chem. Eng. 18, 59-65.

Louw, L., Roux, K., Tredoux, A.G.J., Tomic, O., Neas, T., Nieuwoudt, H.H. \& Van Rensburg, P., 2009. Characterization of selected South African young cultivar wines using FTMIR spectroscopy, gas chromatography, and multivariate data analysis. J. Agric. Food Chem. 57, 2623-2632.

Martínez-Lapuente, L., Guadalupe, Z., Ayestarán, B., Ortega-Heras, M. \& Pérez-Magariño, S., 2013. Sparkling wines from alternative red and white varieties. Am. J. Enol. Vitic. 64(1), 39-49.

Mato, I., Suárez-Luque, S. \& Huidobro, J.F., 2005. A review of the analytical methods to determine organic acids in grape juices and wines. Food Res. Int. 38, 1175-1188.

Minnaar, P.P. \& Booyse, M., 2004. Differentiation between wines according to geographical regions in the Western Cape (South Africa) using multivariate analysis based on selected chemical variables in young red wines. S. Afr. J. Enol. Vitic. 2(2), 89-93.

Nielsen, M.K. \& Arneborg, N., 2007. The effect of citric acid and pH on growth and metabolism of anaerobic Saccharomyces cerevisiae and Zygosaccharomyces bailii cultures. Food Microbiol. 24(1), 101-105.

Nurgel, C., Pickering, G. \& Inglis. D.L., 2004. Sensory and chemical characteristics of Canadian icewines. J. Sci. Food Agric. 84(13), 1675-1684.

Oliveira, J.M., Faria, M., Sá, F., Barros, F. \& Araújo, I.M., 2005. C6alcohols as varietal markers for assessment of wine origin. Anal. Chim. Acta 563, 300-309.

Ott, R.L., 1998. An introduction to statistical methods and data analysis. Duxbury Press, Belmont, CA. pp. $807-837$.

Pigeau, G.M., Bozza, E., Kaiser, K. \& Inglis, D.L., 2007. Concentration effect of Riesling Icewine juice on yeast performance and wine acidity. J. Appl. Microbiol. 103, 1691-1698.

Ribéreau-Gayon, P., Dubourdieu, D., Donéche, B. \& Lonvaud, A., 2000. Handbook of enology. Wiley \& Sons, Ltd., Chichester, England.

Ribéreau-Gayon, P., Glories, Y., Maujean, A. \& Dubourdieu, D., 2006 (2 $2^{\text {nd }}$ ed). Handbook of enology: The chemistry of wine and stabilization and treatment. John Wiley \& Sons, Ltd.

Shapiro, S.S. \& Wilk, M.B., 1965. An analysis of variance test for normality (complete samples). Biometrika 52, 591-611.

Shellie, K.C., 2007. Viticultural performance of red and white wine grape cultivars in Southwestern Idaho. Hort. Technol. 17, 595-603.

Shiraishi, M., Fujishima, H. \& Chijiwa, H., 2010. Evaluation of table grape genetic resources for sugar, organic acid, and amino acid composition of berries. Euphytica 174, 1-13. 
Stratil, P., Kubáń, V. \& Fojtová, J., 2008. Comparison of the phenolic content and total antioxidant activity in wines as determined by spectrophotometric methods. Czech J. Food Sci. 26, 242-253.

Tarko, T., Duda-Chodak, A., Sroka, P., Satora, P. \& Jurasz, E., 2010. Polish wines: Characteristics of cool-climate wines. J. Food Compos. Anal. 23, 463-468.

Tita, O., Bulancea, M., Pavelescu, D. \& Martin, L., 2006. The role of the organic acids in the evolution of the wine. CHISA $2006-17$ th Int. Cong. Chem. Chem. Proc. Praha. pp. $27-31$.

Torresi, S., Frangipane, M. \& Anelli, G., 2011. Biotechnologies in sparkling wine production. Interesting approaches for quality improvement: A review. Food Chem. 129(3), 1232-1241.

Usseglio-Tomasset, L., 1995 (4 ${ }^{\text {th }}$ ed). Chimica enologica. AEB, Brescia.

Vahl, J.M. \& Converse, J.E., 1980. Ripper procedure for determining sulphur dioxide in wine: Collaborative study. J. Assoc. Off. Anal. Chem. 63, 194-199.
Vilanova, M., Genishev, Z., Masa, A. \& Oliveira, J.M., 2010. Correlation between volatile composition and sensory properties in Spanish Albariño wines. Microchem. J. 95, 240-246.

Volschenk, H., Van Vuuren, H.J.J. \& Viljoen-Bloom, M., 2006. Malic acid in wine: Origin, function and metabolism during vinification. S. Afr. J. Enol. Vitic. 27, 2-17.

Weldegergis, B.T., De Villiers, A. \& Crouch, A.M., 2011. Chemometric investigation of the volatile content of young South African wines. Food Chem. 128, 1100-1109.

Willershausen, B., Callaway, A., Azrak, B., Kloß, C.H. \& Schulz-Dobrick, B., 2009. Prolonged in vitro exposure to white wines enhances the erosive damage on human permanent teeth compared with red wines. Nutr. Res. 8, 558-567. 